\title{
PARECERES
}

\section{CONCURSO PÚBLICO - SERVENTIAS DE JUSTIÇA - SEGUNDA ESCOLHA}

\section{PARECER}

I

A consulta tem como fundamento a apreciação de mandado de segurança no qual é postulada a nulidade de atos de provimento de cargos em serventias da justiça, decorrentes de concurso realizado pelo Tribunal de Justiça do Estado do Rio de Janeiro.

O concurso foi promovida com apoio em Edital baixado pela Corregedoria Geral da Justiça, de 9 de outubro de 1998, abrindo seleção pública para delegação em atividades notariais mediante manifestação de escolha a ser feita pelos candidatos na ordem de classificação, durante o prazo de dois anos a partir da homologação do resultado final do certame.

Na hipótese, consumado o concurso classificatório e homologado o resultado, foram os candidatos aprovados intimados a comparecer a audiência pública para declarar a escolha entre as serventias vagas.

Feitas as opções individuais foram publicados os atos de designação específica, cabendo aos escolhidos apresentar, para efeito de investidura, os planos de instalação das serventias escolhidas.

Somente com o oferecimento destes planos de instalação ultimava-se o ato complexo do direito ao provimento no cargo público.

Alguns dos candidatos, alegando a inviabilidade econômica da serventia para a qual foram designados, ofereceram atos de desistência com expressa manifestação pelo direito de exercer nova escolha por outra serventia, dentro do prazo de validade do concurso.

Nesse sentido se manifestou, em petição de $1^{\circ}$ de março de 1999, o candidato Jaime Eduardo Simão.

Com base em tais pronunciamentos, o Presidente do Tribunal tornou sem efeito as designações feitas, tendo o Terceiro Vice-Presidente do Tribunal deferido o pedido de nova escolha.

A decisão do Terceiro Vice-Presidente (emitida em 25 de maio de 1999 (fls. 83/84 dos autos do mandado de segurança) no impedimento do Desembargador Corregedor Geral, está. assim exposta e fundamentada:

"Os candidatos no prazo designado para a apresentação da estrutura material de funcionamento da serventia, ou seja antes do dia $1^{\circ}$ de abril de 1999, declararam a inviabilidade econômica dos serviços.

A investidura no cargo de notário e registrador é ato jurídico complexo, que se encerra apenas com a posse e o consequiente exercício.

Assim, no caso, não se aperfeiçoou a investidura dos requerentes porque não puderam tomar posse, em face das justas razões que os impediram e que não foram geradas por eles.

Por conseguinte, dentro do referido biênio, é possível nova escolha, apenas, aos candidatos que ainda não aperfeiçoaram o ato complexo pois não são ainda notários ou registradores.

Repudiada, portanto, a escolha anterior no prazo assinado aos candidatos e por motivos justificados, procede a pretensão dos postulantes.

Em conseqüência, defiro os pedidos.

Publique-se. 
Rio de Janeiro, 25 de maio e 1999

Des. Semy Glanz

Terceiro Vice-Presidente

(ante o impedimento do eminente Des. Corregedor-Geral da Justiça)

Ficou, assim, expressamente resguardado o direito dos candidatos convocados à continuidade do procedimento de investidura e à opção por nova escolha.

Os candidatos que, por esse forma, optaram por nova escolha foram convocados para audiência pública, realizada em 26 de maio de 1999 e manifestaram sua opinião, habilitando-se ao correspondente provimento.

\section{II}

Contudo, um dos candidatos limitou-se a declarar a desistência para a serventia vaga para a qual fora designado, omitindo qualquer ressalva ou pedido de nova escolha para outra vaga. Por essa omissão foi entendido o seu pedido como desistência plena do direito ao provimento em outro cargo, diante dos termos sumários da petição assim redigida:

"Evandro Ramos Lourenço ... vem mui respeitosamente comunicar a V. Exa. que desistiu de obter a delegação atinente ao Cartório do $2^{\circ}$ Ofício da Comarca de Nilópolis, deixando, pois, de apresentar a respectiva documentação nesta data".

Foi, em consequiência, determinado o cancelamento do ato de sua designação (Ato Executivo $n^{\circ} 1351 / 99$, em 27 de abril de 1999).

Diante do favorecimento dos candidatos que optaram pelo direito a uma segunda escolha (que lhes veio a ser facultada) o candidato acima citado impetrou mandado de segurança, sob $\mathrm{n}^{\circ} 868 / 99$, em 21 de setembro de 1999, no qual alegou violação de direito por não ter sido convocado para o exercício da segunda opção, facilitada aos outros candidatos.

O Corregedor Geral da Justiça, nas informações prestadas nos autos, claramente distingue, porém, as duas situações jurídicas: a do impetrante e a dos outros candidatos, litisconsortes passivos no mandado de segurança.
Destaca o Desembargador informante que o impetrante, ao deixar de completar o ato da escolha inicial da serventia "sem qualquer fundamentação e sem nada requerer, incidiu na cominação prevista na sua parte final, renunciando, tacitamente, à delegação. Daí ter sido ela tornada sem efeito pelo Presidente deste Tribunal, o que implica na sua inabilitação por não ter cumprido uma das etapas do certame, às quais deverão sujeitar-se todos os concorrentes".

Daí a conclusão de que a desistência "nas circunstâncias em que a fez o suplicante, equivale, induvidosamente, à eliminação do concurso, independentemente de qualquer ato formal".

$\mathrm{E}$, distinguindo a situação dos demais, salienta que “já os litisconsortes, bem ao invés, examinaram as condições dos serviços cuja titularidade lhes foram delegada, fundamentadamente, e repudiaram a delegação, pleiteando, porém, nova escolha, o que os manteve no torneio fundados no Regulamento e no Edital" (fls. 168 do mandado de segurança).

\section{III}

Em suma, no tocante aos candidatos que, repudiando a primeira delegação, expressamente manifestaram o intuito de permanecer no procedimento seletivo, reivindicando a viabilidade de uma segunda escolha por outra serventia rentável, o ato complexo do procedimento manteve-se íntegro e veio a se completar quando, em nova convocação de audiência pública, exprimiram o ato de escolha cuja execução prosseguiu nos termos do Edital.

É, inclusive, irrelevante que, em certo momento, o candidato Jaime Eduardo Simão tenha admitido a desistência da opção, posto que a declaração se tornou caduca na medida em que a Administração não the deu eficácia, admitindo a continuidade de sua presença no certame, com a subsequiente convocação para o exercício da segunda escolha, que se efetivou. 
Diante do exposto, passamos a responder aos quesitos expostos na consulta.

Primeiro: É válido o procedimento de segunda escolha pelos candidatos que ora figuram como assistentes litisconsorciais no mandado de segurança?

Resposta - O edital de licitação, para provimento das serventias tem prazo certo e determinado para a efetivação de seu resultado, a saber, o investimento dos candidatos aprovados nos cargos pelos quais tenham optado, com a satisfação dos correspondentes planos de instalação.

A simples escolha de determinada serventia não completa o ato complexo de investidura, cumprindo que, pela segunda etapa, se evidencie a viabilidade da investidura a ser tornada efetiva em ato administrativo do Tribunal.

Consequientemente, enquanto não se vencer o prazo estipulado no Edital, nada impede que a primitiva escolha seja revista e, mediante aprovação da Presidência do Tribunal, outra se manifeste para a consumação do provimento, com o cumprimento do segundo ato que vem integrar a delegação inicial, possibilitando o legítimo investimento do candidato na situação funcional.

Ademais de sua intrínseca validade, o procedimento de segunda escolha foi expressamente consentido em ato da administração superior do Tribunal, dentro do prazo de legitimidade do certame seletivo. É situação líquida e certa, de inequívoca validade.

Segundo - Houve violação dos princípios da isonomia e do concurso público consistente em a não-convocação do impetrante a participar da audiência pública de segunda escolha, considerando-se que o mesmo não havia requerido essa segunda opção?

Resposta - O procedimento regulado pelo Edital é compativel com a opção que viesse a ser feita, por qualquer dos candidatos, no sentido de desistir da primeira manifestação e optar pela possibilidade de nova escolha. Não é, porém, imperativa a dualidade de expressões de vontade a ser manifestada pelos candidatos, cabendo ao Tribunal apenas a

aprovação dos que assim se evidenciarem desejosos de renovação do ato declaratório. Para os que tal não pleitearem é suficiente o ato original, ao qual cumpria-lhes dar continuidade ou dele desistir, encerrando, a seu respeito, o procedimento de escolha, como ocorreu com o impetrante do mandado de segurança, com expresso reconhecimento da autoridade competente.

Terceiro - Houve violação do principio da publicidade na publicação concisa da decisão do Terceiro Vice-Presidente que acolheu os pedidos de segunda escolha dos assistentes litisconsorciais?

Resposta - A publicidade feita, reportando-se ao processo específico, permite aos interessados no procedimento seletivo o conhecimento do mérito da decisão que, por sua natureza, integra a realização do certame que compreende a prática de atos complexos, de etapas definidas no Edital e, portanto, de pleno conhecimento dos interessados, diretamente inscritos no tramite executivo do processo em andamento regular. São eles os destinatários certos e exclusivos aos quais é dada a devida ciência.

Quarto - Houve violação do princípio da publicidade na realização da audiência de segunda escolha sem a convocação pessoal do impetrante nem a publicação prévia no órgão oficial, ocorrendo tão-somente a intimação pessoal dos candidatos ainda habilitados a exercerem segunda opção?

Resposta - Como acima destacado, a segunda manifestação de vontade na escolha da serventia a ser provida, embora compativel com o modelo de procedimento do Edital, tinha como pressuposto que para esse fim houvesse manifestação expressa de vontade dos candidatos aptos a fazer a nova escolha. Não era ato de rotina, nem determinação própria do Edital que a tanto obrigasse todos os candidatos. Obviamente, limitava-se aos que assim houvessem reivindicado novo pronunciamento. Era, em suma, válida, porém, não obrigatória, a segunda escolha. Daí a intimação pessoal de seus favorecidos.

Quinto - Padece de vício o procedimento de nomeação dos assistentes litisconsorciais 
em razão de atos administrativos que teriam sido praticados pelo Corregedor Geral?

Resposta - O impedimento do então Corregedor-Geral (dada a participação de sua esposa no certame) fora objeto de consideração específica em parecer exarado pela Juíza Auxiliar da Corregedoria (fls. 82 do MS). O Corregedor reconheceu expressamente o impedimento, enviando os autos do procedimento administrativo para seu substituto legal - o Terceiro Vice-Presidente (ainda fls. 82 do MS) para tomada de atos decisórias.

Assim é que o Corregedor Geral não praticou nenhum ato administrativo decisório, praticando apenas atos do expediente, e encaminhando os autos às autoridades competentes para as decisões: o presidente ou o Terceiro Vice-Presidente do Tribunal. Deste modo, a decisão que defere a segunda escolha foi tomada pelo Terceiro VicePresidente, e as designações foram da lavra do Presidente do Tribunal. A audiência pública de segunda escolha foi dirigida por Juíza Auxiliar, que, embora seja filha do Corregedor, não guarda nenhuma relação com qualquer dos candidatos, nem com a esposa do Corregedor-Geral, não restando impedida a nenhum título.

Cumprindo as designações, o CorregedorGeral deu posse aos assistentes litisconsorciais (fls. 108 do MS), salvo à sua esposa, que recebeu posse do Terceiro Vice-Presidente (fls. 117 do MS).

De toda sorte, os atos decisórios praticados pelas autoridades impetradas observaram rigorosamente a ordem de classificação dos candidatos, não havendo que se falar em nulidade.

Por fim, ressalte-se que o alegado impedimento não alcança o consulente, que não possui qualquer relação com o Corregedor, além de estar colocado à frente da esposa do Corregedor na ordem de classificação, não sendo alcançado por qualquer eventual nulidade (utile per inutile non vitiatur).

Sexto - Houve desistência tácita no que concerne à anterior desistência em relação ao exercício da segunda opção quanto ao candidato Jaime Eduardo Simão, uma vez que o candidato foi intimado e compareceu à audiência pública, tendo efetivamente exercido a opção e ingressado no cargo, o qual permanece exercendo desde então?

Resposta - Dissemos acima, em relação ao candidato em causa, que a parte final de sua petição, em que alude à desistência de anterior, perdeu eficácia na medida em que, a posteriori, praticou o ato de segunda opção e usufruiu os seus efeitos com a investidura na serventia de escolha final. A continuidade na conduta do candidato importou, assim, em tácita desistência de renúncia a um ato que, em verdade, veio a praticar e cujos efeitos foram reconhecidos pelo Tribunal, dandolhes o devido cumprimento.

Sétimo - Tem procedência o mandado de segurança no qual o candidato Evandro Ramos Lourenço pleiteia a anulação do procedimento, a partir da deliberação permissiva da segunda escolha, restaurando-se sua participação na concorrência pelas vagas existentes?

Resposta - Por todo o exposto nas respostas anteriores e na parte expositiva do parecer, é válida, a nosso ver, a solução adotada quanto aos demais candidatos conducente à continuidade da garantia de escolha de serventia vaga, não havendo nulidade que possa motivar a anulação parcial do procedimento, como pede o impetrante.

Este último conferiu o caráter definitivo e sem ressalva à sua desistência, como acima destacado, logo não havia porque ser convocado para audiência pública na qual se completava a habilitação tão-somente dos candidatos que permaneciam como potenciais beneficiários a nova delegação em virtude de expressa autorização do Vice-Presidente do Tribunal à solicitação feita para esse fim.

Oitavo - Em face da Regulamentação do concurso constante da Resolução 07/97, é válida a previsão do edital do concurso de que os candidatos poderiam ingressar, mediante delegação, nas atividades notariais e de registro de quaisquer serventias (além daquelas previstas no Anexo II do edital) que viessem a vagar no prazo de dois anos contados da homologação do resultado final do concurso?

Resposta - A Resolução $n^{\circ}$ 07/97 é um ato de caráter normativo com o qual se completa a moldura legal da competência administrati- 
va, iniciada com a Constituição, completada nas leis e decretos e ultimada nos atos regulamentares.

Dentro do quadro normativo de legalidade formal, a autoridade administrativa pratica o poder de agir, promovendo atos de execução, com obediência à finalidade dos preceitos normativos. Esta é a natureza do Edital de 8 de outubro de 1998.

São instantes que se não confundem: o de editar atos normativos de sentido abstrato sobre determinada matéria e o de, fundado no conjunto normativo, praticar-se atos de execução. Nesses dois planos se distingue a posição do Regulamento (ato normativo) e o Edital (ato executivo).

Quando o Edital regula, especificamente, os efeitos de determinados concursos públicos cumpre-lhe firmar o prazo de validade do procedimento realizado.

Nem seria admissível um efeito instantâneo, nem a adoção de um prazo indeterminado, ou excessivo, de eficácia que ultrapassasse os limites de razoabilidade.
É legítimo, assim, que, respeitando o rito do Regulamento, possa o Edital em causa marcar prazo para a durabilidade dos efeitos da classificação alcançada pelos candidatos ao concurso e a garantia do direito de investidura nas serventias vagas ou que venham a vagar pelo prazo de dois anos de homologação do certame como expressamente determinado no item $I$, in fine.

São momentos distintos e sucessivos, o primeiro estático e o segundo dinâmico. A norma legal genérica encontra na regra executiva a especificidade da solução própria de cada caso. São situações que se completam, mas não se confundem, visando a atingir um resultado administrativo necessário à hipótese.

Respondemos, por este motivo, no sentido da validade da previsão do edital quanto à vigência dos efeitos da classificação dos candidatos aprovados.

Este é nosso parecer.

Rio de Janeiro, 10 de abril de 2001

CAIO TÁCITO 